DOI: $10.22616 /$ REEP.2020.014

\title{
Prospective Music Teacher Training: Factors Contributing to Creation of Positive State in the Process of Vocal Education
}

\author{
Asta Rauduvaite் ${ }^{1}$ Dr.paed.; Zhiyu Yao ${ }^{2}$ \\ Vytautas Magnus University, Education Academy, Vilnius \\ asta.rauduvaite@vdu.lt ${ }^{1}$; zhiyu.yao@stud.vdu.lt ${ }^{2}$
}

\begin{abstract}
In their study process prospective music teachers have to acquire core knowledge, abilities and skills of vocal education as well as to develop not only subject-specific but also general competences. A future music teacher links her/his identity with the role of both a teacher and a music performer, seeking a harmony between these roles. Thus, while pursuing full-fledged education, emotional experiences of prospective teachers and their positive emotional state in the process of vocal education become of utmost importance. The aim of the study is to reveal the factors contributing to creation of positive state in the process of vocal education. Theoretical research methods: analysis of scholarly literature sources. Empirical research methods: quantitative (prospective teachers' written questionnaire consisting of close-ended questions) and qualitative (prospective teachers' written questionnaire consisting of open-ended questions, semi-structured interview). The collected research data were processed employing quantitative (calculation of percentage frequencies) and qualitative (content analysis of responses) analysis. The research results reveal that preparation for classes, students' mood, physical condition, quality of repertoire and teacher's guidance are seen as the factors that have the strongest impact on future music teachers' positive state during their vocal education. Striving for a positive state of future music teachers in the process of vocal education, it is necessary to identify and analyse these factors to find the best ways to improve this state in vocal education.
\end{abstract}

Keywords: creation of positive state, teacher training, music education, university education.

\section{Introduction}

Under the influence of social and cultural progress, the subject of vocal music has become diversified (European Commission..., 2013). Therefore, now it can be analysed from different perspectives and is considered a very special art subject (Girdzijauskienè, Jankevičienè, Jankuvienè-Rimkuté, 2017; Jucevičiūtė-Bartkevičienè, 2017; Franco et al., 2014; Hunter, Schellenberg, Schimmack, 2010). Learning vocal music, students are required to master the basic vocal methods, to have rich expressive force in singing and a healthy psychological state of mind. R. Kirliauskiene (2018) claims that performing for an audience is one of the most widely spread forms of social anxiety which affects many people. Fear was revealed to be one of the most common causes of unsuccessful performance. This, added to the fact that prospective music teachers also need to be the performers of a very wide range (vocalists, instrumentalists, conductors, managers of non-professional singers or members of an orchestra), means that the possibility of experiencing negative emotions becomes all the more likely.

Perception, mastering and conveyance of change in senses, emotions and moods encoded in poetic and music texts, evoking of emotional experiences and their deepening make up an integral part of emotional music education (Jucevičiūtè-Bartkevičienè, 2017; Pečeliūnas, 2003;). A particular emphasis is laid on evoking positive emotions and experiences and developing empathy through emotional experience of vocal music. According to R. Vasiliauskas (2005), emotions make up an important component in the value structure and the values are frequently determined as immediate emotional reactions of an individual. Thus, emotional experiences, positive emotional state acquire utmost importance to a learner in the process of vocal education. Meaningful comprehension of the text of vocal composition, the analysis of poetic action and linking of these two processes with the musical context as well as living through them are reflected in emotional esthetical vocal expression and a positive state of a learner.

The direct, strong and entertaining function of music art itself is also directly related to university students. The improvement of the spiritual world and the sublimation of the soul are the functions of their spiritual cultivation. Having experienced or still experiencing more intense mental pressure, having a peaceful harmony of body and mind is still an important and realistic need for them (Hallam, 2010). Furthermore, when prospective music teachers attach too much importance to vocal music practice, they 
develop a certain dependence, fear of stage performances and inability to perform at the level they are usually able to. In this regard, teachers are required to intensify the stage practice teaching, to enrich students' stage experience and to help improve learners' comprehensive ability. Secondly, teachers can organize school celebrations, concerts and other activities to provide students with a chance to perform on the real stage, which is conducive to cultivating their psychological quality and stage experience, thereby improving the quality and efficiency of their teaching (Girgin, 2017). What is more, according to E. Panadero, J. Alonso-Tapia, E. Reche (2013), psychology is an interdisciplinary subject in vocal education. It is imperative for vocal music teachers to master this knowledge of the subject.

Teaching practice and artistic practice have proved that the psychological teaching method of vocal music should be used in both group and individual classes. Psychology aims to broaden the knowledge, enhance the depth of knowledge, improve the structure of knowledge, and provide material basis and spiritual means for the education and development of talented vocal music students. It is known that singers have to master many abilities. The first is the basic ability, which includes the feeling of sound level, sound intensity, sound length and sound loudness. The second is advanced ability, which embraces the sense of rhythm, timbre, volume, harmonious control and timbre control. The third is the ability of imagination and memory, which comprises auditory imagery, muscular motor imagery, creative imagery and learning ability. The fourth ability includes association, reflection, musical intelligence and talent. The fifth is the ability to express emotions, including aesthetic, emotional response, emotional expression and such. After the careful analysis, it can be claimed that all these abilities have strong psychological characteristics. This shows that singing contains complex and various psychological qualities and confirms the important role psychology plays in the process of vocal education.

Based on the research of scientists who study the subjects of vocal education and singing psychology (Wang, 2018; Wu, 2018), the further understanding of the importance of singing psychology and making of the proper and reasonable use of it in vocal education, will undoubtedly improve vocal music classroom teaching. Therefore, attention should be paid to the following aspects: the importance of singing psychology and application of singing psychology in vocal education as well as to ways to create a positive state in the process of learning and teaching vocal music.

On the basis of the aforesaid, the problem question is raised: what factors allow and contribute to improvement of prospective music teachers' positive state in the process of vocal education.

The aim of the study is to disclose the factors contributing to creation of positive state in the process of vocal education.

\section{Methodology}

The objectives of the research: to determine certain factors of creating positive state in the process of prospective music teachers' vocal education; to reveal the attitude of prospective music teachers towards meaningfulness of vocal education from the perspective of positive state creation. Theoretical research methods: analysis of scholarly literature sources. Empirical research methods: quantitative (prospective teachers' written questionnaire consisting of close-ended questions) and qualitative (prospective teachers' written questionnaire consisting of open-ended questions, semi-structured interview). The collected research data were processed employing quantitative (calculation of percentage frequencies) and qualitative (content analysis of responses) analysis.

A specially designed questionnaire was used in the research, which consisted of the questions about the significance of factors influencing creation of positive state in the process of vocal education. The questionnaire consisted of 12 statements (factors) and 12 analogous grading scales. The respondents were requested to respond to the statements indicating whether the factor was highly significant, significant or not highly significant. To reveal the attitude of prospective music teachers towards development of positive state, a semi-structured interview was applied. The interview consisted of openended questions on peculiarities of positive state creation. Open-ended questions encouraged students to provide more-detailed responses, which were not restricted by the specific variants for answers. The interview focused on the subjective opinion of research participants. The sample of written questionnaire included 245 respondents; 10 students of music education were interviewed. 


\section{Results and Discussion}

The analysis of the data on students' experience in the process of vocal education. The interviewees were asked questions about their own experience in the process of vocal education. The purpose of the interview was to find out what problems the students face in singing classes, what factors influencing their emotional state during these classes they can identify and what solutions to the existing problems they can point out.

To begin with, Table 1 reveals the students' responses regarding the challenges they have faced (or may be still facing) during the process of singing.

Table 1

Problems encountered in the process of vocal education

\begin{tabular}{|c|c|c|}
\hline Category & Subcategories & Example of quotes \\
\hline \multirow[t]{2}{*}{$\begin{array}{l}\text { Problems } \\
\text { in the } \\
\text { process } \\
\text { of vocal } \\
\text { education }\end{array}$} & $\begin{array}{l}\text { Technical } \\
\text { problems }\end{array}$ & $\begin{array}{l}\text { I can't find the singing position. Generally, I know that my position is } \\
\text { correct only when the teacher tells me so. There are also some problems of } \\
\text { pronunciation and word-biting. These are my biggest problems at present. I } \\
\text { can't tell if I am singing well or not. } \\
\text { Lack of relaxation and unstable breathing tend to affect the integrity of my } \\
\text { performance of a song. } \\
\text { My biggest problem is learning the lyrics of a foreign song. }\end{array}$ \\
\hline & $\begin{array}{l}\text { Psychological } \\
\text { problems }\end{array}$ & $\begin{array}{l}\text { In singing classes, I experience too much psychological pressure. } \\
\text { I have issues with stage-fright. I feel tensed and nervous before going on } \\
\text { stage, although when I start performing, I usually tend to find my pace and } \\
\text { my nervousness dissipates. } \\
\text { I overanalyse things and tend to focus on certain aspects of my vocal } \\
\text { performance that I feel are not good enough. I think these psychological } \\
\text { problems often lead to technical problems. }\end{array}$ \\
\hline
\end{tabular}

The results show that many prospective music teachers have different degrees of psychological problems as well as issues related to the lack of certain musical skills. Many interviewees listed technical problems as the reason for their poor state of wellbeing in vocal education. Not being able to find the correct singing position without explicit help from the teacher, unstable breathing during singing and inability to learn the lyrics of a foreign song were among the main reasons pointed out by the students. The psychological problems included too much pressure, stage-fright, overanalysing things and focusing on their own weaknesses.

The responses revealed that sometimes psychological problems arose from the existing skill problem: for instance, the student had certain technical issues, which led to negative emotions, such as frustration with himself or herself or fear of disappointing the teachers. Consequently, skill problems arose from the existing psychological problems: prospective music teachers were in a poor emotional state or if they suffered from stage-fright, their musical skills were also affected in a bad sense. This allowed concluding that psychological problems and technical problems coexist in many cases (Hedden, 2017).

Table 2 shows examples of the responses regarding the factors that influence the respondents' state during singing classes.

The results revealed that the students' state in the process of vocal education can be affected by various factors. The first one is physical health and living habits. It is well-known that people who learn singing should give up bad habits in order to protect their voice (Hedden, 2019).

The teacher's mood was the major factor affecting the state of the students. If the teacher is angry, the students tend to feel scared, pressured, and inadequate. While it is understandable that teachers have their own emotions, some of which can actually be related to the way the students act in class, their level of preparation for it, and more. All this can trigger a normal psychological reaction from the teacher such as anger, as well as happiness and excitement if that is what they are feeling that day. Nonetheless, the important thing to consider is that the way the teacher expresses their emotions affects the prospective music teachers and their well-being during the classes and they should consider all that. In other words, to create a positive learning environment and cultivate positive states it is necessary for the teachers to control their emotions and deal with prospective music teachers in a calm and professional manner (Powell, Parker, 2017). 
The factors influencing the students' state in class

\begin{tabular}{|c|c|c|}
\hline Category & Subcategories & Example of quotes \\
\hline \multirow[t]{3}{*}{$\begin{array}{l}\text { Factors } \\
\text { influencing } \\
\text { the } \\
\text { students } \\
\text { state } \\
\text { in class }\end{array}$} & Lifestyle & $\begin{array}{l}\text { If I haven't slept well or haven't been eating well and haven't been drinking } \\
\text { enough water, or if I recently drank alcohol, smoked... that would cause } \\
\text { some problems with my singing voice. } \\
\text { The things that influence how I feel during vocal music classes are mostly } \\
\text { sleep quality, eating peppers, and drinking. }\end{array}$ \\
\hline & Teacher's mood & $\begin{array}{l}\text { Of course, if the teacher is very enthusiastic and relaxed, I will dare to sing, } \\
\text { but if the teacher is in a bad mood today, I will be nervous, I fear that the } \\
\text { teacher will be angry. } \\
\text { I think the teacher's mood has the greatest impact on me. If the teacher's } \\
\text { mood is good, my mood will be good, too. If the teacher's mood is not good } \\
\text { that day, I will be very afraid. And under great pressure. }\end{array}$ \\
\hline & Environment & $\begin{array}{l}\text { When the classroom or even the halls are too loud, it's difficult to } \\
\text { concentrate in class and it affects how I feel. } \\
\text { My voice gets strongly affected by the changes in nature and weather, so } \\
\text { when I experience these physical problems, I don't feel well during vocal } \\
\text { music class. }\end{array}$ \\
\hline
\end{tabular}

Understanding that vocal music requires rigorous practice in and outside the classroom, students frequently experienced fear or shame if they came unprepared to the class, which hindered their overall positive state (Abramauskienè, Kirliauskienè, 2018; Pallavicino, 2015). There are environmental factors, which are twofold: the classroom environment and the natural environment. Some prospective music teachers pointed out that because of the shift of seasons, their voices often experienced various problems, which, in return, resulted in their bad feeling in the classroom. This factor obviously cannot be changed and students can only learn to deal with it and prepare for it accordingly. As for the classroom environment, because of the particularity of the specialty, the classroom and further surroundings need to be quiet in order for the students to concentrate on the subject and if there is too much noise and disruption, the students' emotional state may suffer. This may be changed in various ways, for example, locating music classrooms in more reclusive parts of the university, scheduling classes in times when there is not a lot of activity from students of different fields, or soundproofing the classrooms.

The research (Table 3) showed that the solutions to the problems experienced by prospective music teachers in the process of vocal music education are different for each interviewed individual. Some participants tried to eliminate negative factors influencing their state in class using various means, such as drinking water, doing breathing exercises and following teacher's guidance.

Table 3

\section{Suggestions for creating positive states in the process of vocal education}

\begin{tabular}{|c|c|c|}
\hline Category & Subcategories & Example of quotes \\
\hline $\begin{array}{l}\text { Creating } \\
\text { positive states } \\
\text { in the process } \\
\text { of vocal }\end{array}$ & In the class & $\begin{array}{l}\text { I think the first step to feeling better in class is drinking plenty of water } \\
\text { and doing breathing exercises. } \\
\text { I feel less pressure when I listen carefully to the teacher and do my tasks } \\
\text { as good as possible. }\end{array}$ \\
\hline education & After the class & $\begin{array}{l}\text { I think resting after the class and clearing my mind helps. } \\
\text { For me, self-motivation and reflection are most helpful. I try to identify the } \\
\text { reasons for any negative feelings that I experience in class and try to } \\
\text { eliminate the I problem. I also try to keep enthusiastic and tell myself not to } \\
\text { give up. } \\
\text { If I experience negative emotions in class, I try to calm down after it, re- } \\
\text { think what I may have done wrong or where I misunderstood my teacher } \\
\text { and try to correct my mistakes. }\end{array}$ \\
\hline
\end{tabular}

However, the majority of them deal with their problems after class: they either try to relax and clear their mind in a safe environment, or dedicate some time to think and reflect on what happened, what caused negative emotions or experiences and what could be done to improve the situation. According to 
A. Rauduvaite (2018), it is particularly relevant to consider and choose a repertory, which is as if the bridge between the teacher and the learner. This is important because music provides inspiration, joy, helps to relax, evokes previous experiences, appeals to cultural values, stimulates mind and encourages creativity.

The prospective music teachers, who indicated that they feel negative emotions due to misunderstandings with their teacher, also added that that trying to analyse their interactions with the teacher, re-thinking and attempting to understand what the teacher meant or wanted from them in class also helped them not to repeat mistakes and feel better in the following singing classes. Teacher's guidance was distinguished as one more very important factor, which influences the students' positive state in vocal education (Sakadolskienè, 2017; Juslin, Laukka, 2003).

All in all, it can be concluded that while students deal with negative emotions in the classroom in different ways, most of them have their own coping mechanisms to be employed when the need arises. However, it also seems that not all of the efforts are effective or as effective as they could be. Therefore, it is crucial for the students and the teachers to correctly identify all the factors influencing negative states in the process of vocal education in order to change the situation and find appropriate and efficient ways to cope with negative aspects (Johnsos, Matteheus, 2017; Wright, Finney, 2010).

The prospective music teachers made suggestions for the improvement of the process of vocal education based on their own experience (Table 4).

Table 4

\section{Suggestions for improving the learning process of vocal education}

\begin{tabular}{lll}
\hline Category & Subcategories & \multicolumn{1}{c}{ Example of quotes } \\
\hline $\begin{array}{l}\text { Improving } \\
\text { the }\end{array}$ Mentality & The first point is not to be impatient or too eager to achieve goals; it is \\
vocal & necessary to concentrate on practice. \\
education & I think the most important thing is not to give up. Continuous efforts. \\
& Perseverance. That's all. \\
& Idon't think there are any geniuses in the world. As long as we study hard \\
& and constantly, even little progress every day is still progress. Diligence will \\
& make up for ignorance - the world is for those who are prepared. \\
& Learning vocal music is not just singing, you need to understand what the \\
& composer experienced in that era, what kind of mentality created this song, \\
& and then you need to understand the meaning of the lyrics, express certain \\
& emotions. I think that all of these should be considered, as well as respect for \\
& composers and responsibility for works. \\
& Listen more, practice more, see more, learn more about singing, listen to \\
& more good concerts, broaden your horizons, improve self-cultivation. \\
& In the classroom, you must employ self-regulation, and actively cooperate \\
& with teachers. \\
& Reflecting after class, analysing mistakes, also gaining some theoretical \\
knowledge. & Listening to different kinds of music. Listening is very important in music. \\
& More practice. More expression of emotion.
\end{tabular}

\section{The analysis of the data of the questionnaire survey on students' opinion about process of vocal education}

The prospective music teachers were asked if they think that it was important to reflect on the problems in teaching: $47 \%$ of the respondents thought it to be very important, $29 \%$ of them considered it to be important, $16 \%$ claimed importance of the matter in general and $8 \%$ of the respondents did not give any importance to the matter. The students were asked to evaluate the importance of self-assessment: $41 \%$ and $35 \%$ of the prospective music teachers believed that self-assessment is a valuable addition to the positive state in the class. $16 \%$ of the respondents did not give the utmost importance to self-assessment skills and only $8 \%$ of them answered that it was not important at all.

One of the methods often used is listening to the recording of prospective music teachers' singing as a means of self-assessment. The data revealed that $46 \%$ of prospective music teachers agree that this 
method is important for the positive state of learning. However, only $38 \%$ of the respondents thought that the method was also useful for self-assessment. $37 \%$ of prospective music teachers pointed out that it was important and $30 \%$ stated that it was slightly more important for the self-assessment. There was a bigger contradiction in the opinion about general importance, as $11 \%$ of the respondents found listening to the recording of general importance to the positive state during classes. However, about one fourth $(23 \%)$ of the respondents stated that it was not that important for self-assessment. Lastly, only a small proportion (7\% and $9 \%$ ) believed that it was unimportant for the positive state and self-assessment at all.

The students were also asked whether they thought that preparation for singing classes was important in order for them to get a positive state during the actual classes. The majority of the prospective music teachers (43\%) indicated that this was a very important factor for their self-reflection, and $39 \%$ stated that it was more important in general sense than for self-reflection. $15 \%$ and $11 \%$ of the respondents thought it to be of general importance to the positive state and self-reflection, while only a small number of respondents $(8 \%)$ and $(10 \%)$ pointed out that it was not important at all. This allows assuming that positive state of music education students in the process of vocal education is greatly influenced by the level of their preparation before the class. This makes the preparation for vocal music classes an important factor.

One more important factor mentioned by the respondents was their mood, which they were coming into the classroom in. Half of the students $(50 \%)$ answered that their mood at that very moment influenced how they felt during the singing classes. Similarly, the prospective music teachers stressed that their physiological state also had a major influence on their general state during vocal classes, with $40 \%$ and $33 \%$ respectively claiming that their physical health was very important or had a higher level of importance than general and strongly affected their state in the process of vocal education.

As the survey showed, not only the mood but also the general mental state of the students may have a tremendous impact on their positive state. About half of the respondents (45\%) assure that this is a very important factor, while only $7 \%$ of the respondents put no value in a general mental state of the singer.

Furthermore, the respondents highlighted the importance of the quality of the songs they were given to sing during singing classes as an impact on their positive state. That is to say, if the students understand the piece they are singing, if they emotionally connect with it and find it enjoyable to sing, they are likely to be in a positive state while learning, and vice versa. About half of the respondents $(45 \%)$ stated that the liking of the song is very important for a positive state during the class, one third of students (29\%) claimed that it was important, and only a small number of respondents $(8 \%)$ did not give any importance to this factor.

Most of the questioned students stated that the way their teachers conducted the class, explained the tasks and helped them with arising problems significantly affected their state in the process of vocal education: $39 \%$ and $34 \%$ of the respondents stated that this factor was either very important or had an importance and only $11 \%$ claimed that teacher's actions during the class are of no importance to their positive state. This also complied with the results gathered from the interview, in which students claimed that their teacher's mood and guidance were directly related to how they felt in class.

According to the survey data, the respondents distinguished six compound music professional skills that music teachers should develop. The skills include: singing, instrumental performance, music score reading, creativity, conduction, ability to use media. As can be seen, prospective music teachers must take into account many different factors, therefore it is crucial for them to develop in an all-round way and always be open for the innovations.

Apart from skills, the respondents emphasised the importance of qualities that must be present in every music teacher. From the responses, two sub-categories were identified: qualities of personal accomplishment and qualities of professional ethics. Personal accomplishments involve patience, seriousness, responsibility and the psychological knowledge of students' strengths and weaknesses. Professional ethics encompass an attitude towards music, commitment to development and improvement of students, proper feeling of the musical compositions and striving for knowledge and innovations instead of being focused on one method of teaching.

To further delve into the problems that occur during music classes and can hinder the positive state of students, the question about their skills was asked. The main problem for females was their weak abdomen and inability to relax while singing. Males stated that they were not able to control their throat position, which 
often resulted in the pitch not being able to go high enough. Also, a third subcategory, which included the rhythm and was common for both females and males, was identified. The problems embraced their inability to catch up with the rhythm of music, unstable singing atmosphere, inability to evoke and express the correct feeling of musical composition and having an incorrect pronunciation of lyrics in foreign languages. In summary, the positive state is also influenced by physiological factors that differ between genders.

One more aspect highlighted by the respondents embraced problems encountered during actual teaching. In this category four subcategories were distinguished. The subcategories were as follows: communication, coordination, natural personal conditions and teacher's personal problems. Communication problems mainly include the understanding of the theoretical parts without having the actual experience. Learners of different age and different experiences interpret the same musical compositions differently. So the understanding that can be shared by everyone is not easily acquired. Also, some psychological and physiological factors can influence the students' ability or willingness to cooperate with the teacher's guidance and tasks. Personal conditions encompass the inherent physiological state of the student's voice, hearing and other factors that are required for singing and learning music. Finally, teacher's personal problems can involve lack of experience to deal with particular situations or inability to properly guide the student through learning process with their natural characteristics. The respondents were asked about the possible solutions, which can facilitate achievement of positive state. Three main subcategories were identified: students' own condition management, external factors and learning methods. Students should try to regulate themselves. Being in a good mood, having a healthy physiological state and being relaxed enable them to achieve a higher singing desire. Also, having a better knowledge of musical composition helps the learners to do better in their performance, thus enforcing a positive state. External factors involve teacher's guidance and coordination as well as providing a suitable singing environment. Finally, positive state cannot be achieved without proper learning methods, such as listening to critiques and having some self-reflection, as well as seeing and learning from other people's performances at the concerts.

Adequate preparation for classes, overall mood of students, their physical and mental health, the quality and enjoyment of the repertoire and the teacher's guidance were distinguished as the most significant factors influencing positive state of prospective music teachers in the process of their vocal education.

\section{Conclusions}

The prospective music teachers revealed that they experience a variety of technical and psychological problems in the process of vocal education. What is more, it became evident from the respondents' answers that these problems are interrelated: technical problems create psychological ones, and vice versa.

The interviewed prospective music teachers disclosed the internal and external factors which negatively influence their state during singing classes. The internal factors included physical health, while the external factors embraced the teacher's mood, voice problems related to certain weather conditions, and disruptive environment in and around the classroom. The solutions to internal issues proposed by the interviewees included propagating healthy living, drinking plenty of water and getting enough rest. Suggestions for eliminating external problems included promotion of self-motivation, taking time to reflect and analyse the arising issues and trying to correct mistakes or poor patterns of behaviour. Moreover, prospective music teachers should see the link between technical and psychological problems which are enforcing negative emotions in the process of vocal education in order to create positive states. The interviewees also provided some suggestions for improving the learning process of vocal education, putting emphasis on adjustments in students' mentality and employing certain learning methods.

The research shows that the following factors which have the strongest impact on future music teachers' positive state during singing learning: preparation for class; students' mood; physical condition; quality of repertoire; teacher's guidance. Based on these findings, it can be concluded that in order to create a positive state in the process of vocal education, the participants in this process should be able to identify and analyse these factors to find ways to improve the state of prospective music teachers in vocal education. 


\section{Bibliography}

1. Abramauskienė J., Kirliauskienė R. (2018). Analysis of some aspects of music education: approach of school principals. Music science today: the permanent and the changeable. Daugavpils: Daugavpils university academic press "Saule", 2(10), 149-154.

2. European Commission/EACEA/Eurydice. (2013). Education and Training in Europe 2020: Responses from the EU Member States. Eurydice Report. Brussels: Eurydice. Retrieved from http://abdigm.meb.gov.tr/projeler/ois/009.pdf

3. Franco F., Swaine J.S., Israni S., Zaborowska K.A., Kaloko F., Kasevarajan I., Majek J.A. (2014). Affectmatching music improves cognitive performance in adults and young children for both positive and negative emotions. Psychology of music, 42(6), 869-887. doi: 10.1177/0305735614548500

4. Girdzijauskienè R., Jankevičienè Ž., Jankuvienè-Rimkutė S. (2017). Dainavimas be sienu. Vokalinio ugdymo tradicijos ir inovacijos [Singing without Borders. Traditions and Innovations of Vocal Education]. Klaipedda: Klaipedos universiteto leidykla. Retrieved from http://www.lmma.eu/wpcontent/uploads/2018/11/Dainavimas-be-sien\%C5\%B3.pdf (in Lithuanian)

5. Girgin D. (2017). The relations among musical instrument performance self-efficacy, self-esteem and music performance anxiety in pre-service music teachers. Educational Research and Reviews, 12(11), 611-616. doi: 10.5897/ERR2017.3251

6. Hallam S. (2010). The power of music: its impact on the intellectual, social and personal development of children and young people. International Journal of Music Education, 28(3), 269-289. doi: 10.1177/0255761410370658

7. Hedden D.G. (2017). Lessons from Lithuania: A pedagogical approach in teaching improvisation. International Journal of Music Education, 35(2), 289-301. doi: 10.1177/0255761416667462

8. Hedden D.G. (2019). Lessons from Lithuania: Teacher beliefs and behaviors in teaching young children to sing. International Journal of Music Education. doi: 10.1177/0255761419888015

9. Hunter P.G., Schellenberg G.E., Schimmack U. (2010). Feelings and Perceptions of Happiness and Sadness Induced by Music: Similarities, Differences, and Mixed Emotions. Psychology of Aesthetics, Creativity, and the Arts, 4(1), 47-56. doi: 10.1037/a0016873

10. Johnsos C.D., Matteheus W.K. (2017). Experienced general music teachers' instructional decision making. Interpersonal Journal of music education, 35(2), 189-201. doi: 10.1177/0255761415620531

11. Jucevičiūtè-Bartkevičienè V. (2017). The importance of vocal education in preschool institutions. CFMAE: The changing face of music and art education, interdisciplinary journal for music and art pedagogy, 9, 9-17.

12. Juslin N.P., Laukka P. (2003). Communication of Emotions in Vocal Expression and Music Performance: Different Channels, Same Code? Psychological Bulletin, 129(5), 770-814. doi: 10.1037/0033-2909.129.5.770

13. Kirliauskienė R. (2018). The peculiarities of self-regulation of future music teachers during the practice. In E.P. Sheehan (Ed.), The Proceeding of the International Conference on Education, 4, 69-78. doi: 10.17501/icedu.2018.4108

14. Pallavicino A.Z. (2015). Musical play and emotional (self-)regulation a Maieutic-formative teaching method. Procedia - Social and Behavioral sciences, 191, 1629-1633. doi: 10.1016/j.sbspro.2015.04.659

15. Panadero E., Alonso-Tapia J., Reche E. (2013). Rubrics vs. self-assessment scripts effect on self-regulation, performance and self-efficacy in pre-service teachers. Studies in Educational Evaluation, 39(3), 125-132. doi: 10.1016/j.stueduc.2013.04.001

16. Pečeliūnas R. (2003). Vaiku vokalinès kultūros ugdymas chore. [Development of Children's Vocal Culture in Choir]. Šiauliai: ŠU leidykla.

17. Powell S.R., Parker E.C. (2017). Preservice music teachers' descriptions of successful and unsuccessful teachers. Journal of Music Teachers Education, 26(3), 27-37. doi: 10.1177/1057083716662689

18. Rauduvaite A. (2018). The Educational Aspects of Integrating Popular Music into Lessons. In V. Dislere (Ed.), The Proceedings of the International Scientific Conference Rural Environment. Education. Personality (REEP), 11. Jelgava: Latvia University of Life Science and technologies, 94-100. doi: 10.22616/REEP.2018.011

19. Sakadolskienė E. (2017). Ne vien žinios ir gebejjimai: transformacijos per mokytojo socializaciją ir tapatybès ugdymą [Not Just Knowledge and Skills: Transformations in Teacher Socialization and Identity]. Acta Paedagogica Vilnensia, 38, 42-57. Retrieved from https://www.zurnalai.vu.lt/acta-paedagogicavilnensia/article/view/10790/8885 (in Lithuanian)

20. Vasiliauskas R. (2005). Vertybiu pedagogika: ižvalgos $i$ vertybiu ugdymo teorija ir praktika. [Pedagogy of Values: Insights into Theory and Practice of Value Education]. Vilnius: VPU leidykla.

21. Wang X.L. (2018). Research on the cultivation of stage expression in vocal music singing. China: China National Expo, 34(10), 143-154.

22. Wright R., Finney J. (2010). Culture, Society and Music Education. In R. Wright (Ed.). Sociology and Music Education. London: Routledge, 223-241. doi: 10.4324/9781315087856

23. Wu X. B. (2018). Analysis of Vocal Music Learning in Secondary Vocational Schools: Problems and Solutions. Voice of the Yellow River, 35(17), 127-138. 